\title{
SPONTANEOUS PITUITARY ADENOMAS OF THE PARS INTERMEDIA IN MICE AND RATS : HISTOPATHOLOGICAL AND IMMUNOCYTOCHEMICAL STUDIES
}

\author{
Yuji Oishi, Masahiro Matsumoto, Katsuhiko Yoshizawa, \\ and Shiro Fujihira
}

Department of Pathology Toxicology Research Laboratories, Fujisawa Pharmaceutical Co., Ltd.

\author{
Airo Tsubura and Sotokichi Morii \\ Department of Pathology, Kansai Medical University
}

\begin{abstract}
From the control groups of five 2-year carcinogenicity studies, we isolated and observed six pituitary adenomas of the pars intermedia in two mice and four rats by histopathological and immunocytochemical techniques for evidence of production of the following proopiomelanocortin (POMC)-derived peptides; adrenocorticotropic hormone (ACTH), $\alpha$-melanocyte-stimulating hormone $(\alpha$-MSH), $\beta$-melanocyte-stimulating hormone $(\beta$-MSH), $\gamma$-melanocyte-stimulating hormone $(\gamma-$ MSH), and $\beta$-endorphin ( $\beta$-END). Macroscopically, most adenomas were from slightly to moderately enlarged or colored dark red, and were well separated from the brain and surrounding tissues. Histologically, their cells were scarcely distinguishable from the normal pars intermediate cells, but they often contained abundant eosinophilic cytoplasms, were enlarged and occasionally elongated and arranged in parallel groups. Atypia was not seen regularly, but some mitotic figures were seen. Two large adenomas from rats revealed vacuolated cell nests and follicular structures with colloidal materials. Immunostainings of all adenomas in both mice and rats were positive for all antisera tested and scarcely differed from staining of normal pars intermediate cells except that the intensities among the antisera were not constant and often presented pale and speckled appearances. Since the cytoplasms of the vacuolated cell nests of two rat adenomas also reacted positively for POMC-derived peptides, it was clear that these nests also originated from the pars intermedia. No endocrinological abnormalities in other organs or tissues, including the adrenal glands, were detected in any adenoma-bearing animals. From this evidence, we concluded that the adenomas derived from pars intermedia were endocrinologically active and were producing POMC-related peptides in both mice and rats. (J Toxicol Pathol 5: 223 231, 1992)

Key words : Spontaneous tumor, Pituitary gland, Pars intermedia, Rat, Mouse
\end{abstract}

\section{Introduction}

Spontaneous tumors of the pituitary gland are one of the most common neoplasms in aging rats $^{1-5}$. In contrast, spontaneous pituitary tumors are decidedly uncommon in the mice ${ }^{6-8}$. In both

大石裕司 松本正博 義澤克彦 藤平司郎 螺良愛郎

森井外吉

Accepted for publication: August 10, 1992

Mailing address: Yuji Oishi, Department of Pathology, Toxicology Research Laboratories, Fujisawa Pharmaceutical Co., Ltd. Kashima 2-1-6, Yodogawa, Osaka 532, Japan. rats and mice, the majority of pituitary tumors arise from the pars distalis. The histological and immunocytochemical characteristics of these pars distalis tumors have been well described in rats ${ }^{9-14}$ but there are few available papers on the morphology of tumors developed from the pars intermedia owing to the extreme rarity of this tumor ${ }^{9-12}$. Although a few immunocytochemical studies of adrenocorticotropic hormone (ACTH) and/or $\alpha^{-}$ melanocyte-stimulating hormone ( $\alpha-\mathrm{MSH})$ in rat pars intermediate tumors have been reported ${ }^{9-11}$, to our knowledge, no survey of their endo- 
crinological character of mouse pars intermediate tumors has been undertaken up to now.

Biochemical studies have shown that the pituitary pars intermediate cell is a major source of proopiomelanocortin (POMC)-derived peptides and have clarified their profile. The processing of POMC differs between the pars intermedia and the pars distalis. In the pars distalis, POMC is processed predominately to ACTH, $\beta-$ melanocyte-stimulating hormone $(\beta$-MSH), $\gamma-$ melanocyte-stimulating hormone $(\gamma-\mathrm{MSH})$, and $\beta$-endorphin ( $\beta$-END). In the pars intermedia, ACTH is processed further to $\alpha$-melanocyte-stim- ulating hormone ( $\alpha-\mathrm{MSH}$ ), and corticotropin-like intermediate lobe peptide (CLIP) ${ }^{15-17}$.

In the present study, spontaneous adenomas of the pars intermedia in aging mice and rats were investigated with the application of histopathological and immunocytochemical characters to establish the cellular composition and contents of hormones related POMC.

\section{Materials and Methods}

Case histories are presented in Table 1. All mice and rats were obtained from control groups

Table 1. Case Histiories of Pituitary Adenomas Derived from the Pars Intermedia and Other Pathological Findings in Mice and Rats

\begin{tabular}{|c|c|c|c|c|c|}
\hline Case & Species & Strains & Sex & $\begin{array}{c}\text { Age } \\
\text { (weeks) }\end{array}$ & $\begin{array}{l}\text { Major pathological findings } \\
\text { of other organs and tissues }\end{array}$ \\
\hline 1 & Mouse & $\mathrm{Crj}: \mathrm{C} 57 \mathrm{BL} / 6$ & Female & 108 & Hepatocellular fatty change \\
\hline 2 & Mouse & $\mathrm{Crj}: \mathrm{B} 6 \mathrm{C} 3 \mathrm{~F}_{1}$ & Female & 102 & $\begin{array}{l}\text { Malignant lymphoma } \\
\text { Hepatocellular carcinoma }\end{array}$ \\
\hline 3 & Rat & Jcl : SD & Male & 110 & $\begin{array}{l}\text { Islet cell adenoma } \\
\text { Chronic nephropathy }\end{array}$ \\
\hline 4 & Rat & $\mathrm{Jcl}: \mathrm{SD}$ & Male & 89 & $\begin{array}{l}\text { Astrocytoma of brain } \\
\text { Thyroid C-cell adenoma } \\
\text { Chronic nephropathy }\end{array}$ \\
\hline 5 & Rat & Jcl : SD & Male & 102 & $\begin{array}{l}\text { Pancreatic adenoma } \\
\text { Subcutaneous fibroma }\end{array}$ \\
\hline 6 & Rat & Jcl : SD & Female & 110 & Mammary fibroadenoma \\
\hline
\end{tabular}

Table 2. Macroscopic and Histopathological Features of Pituitary Adenomas Derived from the Pars Intermedia in Mice and Rats

\begin{tabular}{|c|c|c|c|c|}
\hline Case & $\begin{array}{l}\text { Gross } \\
\text { findings }\end{array}$ & Growth pattern & Cell arrangement & Cell morphology and components \\
\hline 1 & Dark red & $\begin{array}{l}\text { Invaded } \\
\text { pars nervosa }\end{array}$ & Sinal dilatation & Similar to normal cells \\
\hline 2 & Enlarged & Expansive & $\begin{array}{l}\text { Trabecular and } \\
\text { arranged in cords }\end{array}$ & $\begin{array}{l}\text { Large elongated cells } \\
\text { with prominent nucleoli } \\
\text { Some mitosis }\end{array}$ \\
\hline 3 & $\begin{array}{l}\text { Dark red } \\
\text { focus }\end{array}$ & $\begin{array}{l}\text { Invaded } \\
\text { pars distalis }\end{array}$ & Sinal dilatation & $\begin{array}{l}\text { Atypical giant cells } \\
\text { Large eosinophilic cells } \\
\text { with prominent nucleoli } \\
\text { Some mitosis }\end{array}$ \\
\hline 4 & Enlarged & $\begin{array}{l}\text { Replaced } \\
\text { pars nervosa }\end{array}$ & Alveolar & $\begin{array}{l}\text { Slight eosinophilic cells } \\
\text { Colloidal follicular structures } \\
\text { Vacuolated cell nests } \\
\text { A cyst lined by ciliated epithelium }\end{array}$ \\
\hline $5^{*}$ & Enlarged & $\begin{array}{l}\text { Replaced } \\
\text { pars nervosa }\end{array}$ & Closely packed & $\begin{array}{l}\text { Slight eosinophilic cells } \\
\text { Vacuolated cell nests } \\
\text { Colloidal follicular structures }\end{array}$ \\
\hline 6 & NAD & $\begin{array}{l}\text { Compressed } \\
\text { pars nervosa }\end{array}$ & Closely packed & $\begin{array}{l}\text { Slight eosinophilic cells } \\
\text { with prominent nucleoli }\end{array}$ \\
\hline
\end{tabular}

\footnotetext{
* : Case 5 associated with a adenoma of the pars distalis. NAD : no abnormality detected.
} 
of five long-term carcinogenicity studies on new drugs for safety assessment in Toxicology Research Laboratories of Fujisawa Pharmaceutical Co. Ltd. Throughout these studies the animals were housed in polycarbonate cages in an animal room at $23 \pm$ $2{ }^{\circ} \mathrm{C}$ room temperature, $55 \pm 5 \%$ relative humidity, and with a $12: 12 \mathrm{hr}$ light-dark sequence. All animals were given a standard radiation-sterilized powder diet (CA-1, CLEA Japan Inc., Tokyo) and water freely. The animals were routinely observed for morbidity and mortality twice daily, and any abnormalities were recorded.

All animals that died or were killed received a complete necropsy examination. The pituitary gland and many of the routinely examined organs and tissues were fixed in $10 \%$ buffered formalin, embedded in paraffin, sectioned, and stained with hematoxylin-eosin (H.E.). Additional sections of the pituitary glands diagnosed as pars intermediate adenoma, were stained with an avidin-biotincomplex immunoperoxidase method (ABC-Elite,

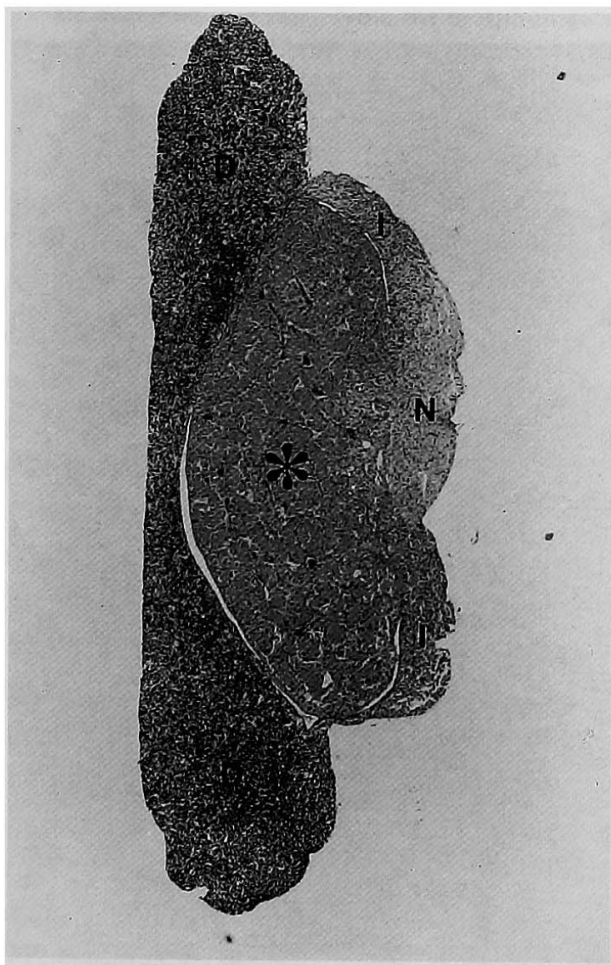

Fig. 1. Pars intermediate adenoma ( $*$ ) of a mouse pituitary gland showing compressions of the pars distalis (D), the pars nervosa (N), and the normal pars intermedia (I). Case 2., H.E., $\times 30$
Vector Laboratories, CA, USA) for POMCderived peptides: $\mathrm{ACTH}^{1-39}$ (Advance Inc. Tokyo, Japan, dilution $1: 5,000), \quad \beta$-END (MILAB, Malö, Sweden, $1: 500$ ), $\alpha$-MSH (UCBBioproducts, Brussels, Belgium, $1: 2,000), \beta$-MSH (UCB-Bioproducts, $1: 2,000$ ), and $\gamma$-MSH (UCBBioproducts, $1: 1,000$ ). All primary antibodies were rabbit polyclonal antisera, and no cross reaction with each other POMC-derived peptides were confirmed by the suppliers. Sections were incubated with the primary antiserum at $4^{\circ} \mathrm{C}$ overnight and were thoroughly washed with Trisbuffered saline (TBS, pH 7.6, with $0.05 \%$ Tween 20). The final reaction products were visualized with $0.01 \% \quad 3,3^{\prime}-$ diaminobenzidine tetrahydrochloride (DAB, Wako Pure Chemicals, Osaka, Japan) in TBS containing $0.02 \%$ hydrogen peroxide, and the sections were counterstained with hematoxylin.

Before the examination of the pars intermedi-

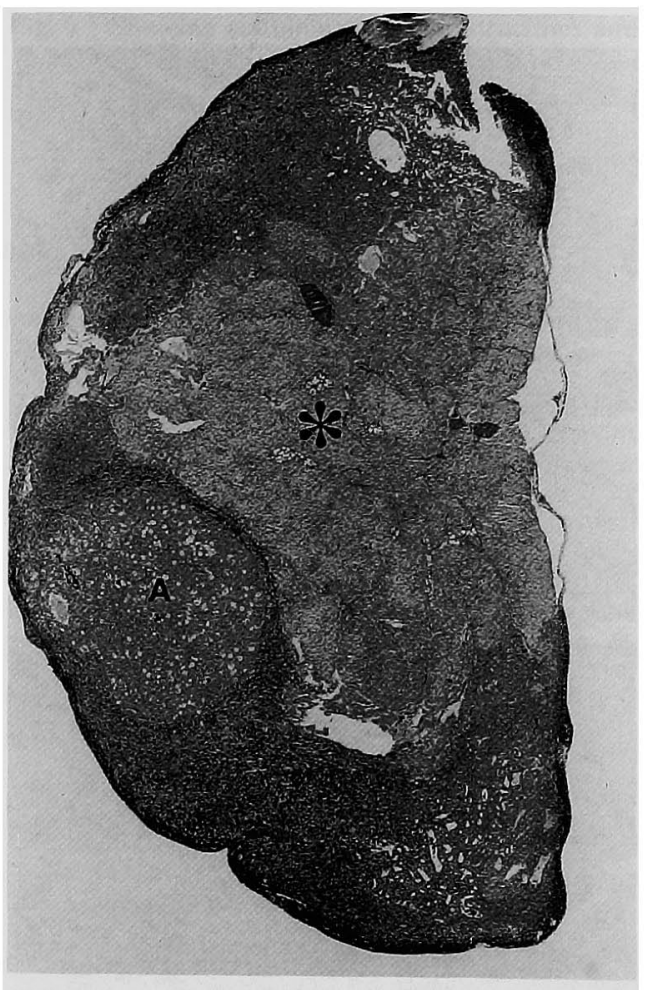

Fig. 2. Pars intermediate adenoma ( $*$ ) of a rat pituitary gland showing replacement of the pars intermedia and nervosa. Note an accomplished micro-adenoma (A) in the pars distalis. Case 5., H.E., $\times 20$ 
ate tumor started, normal pituitary glands of mice and rats were stained with the above 5 antisera. Method controls included substitution of primary antisera with normal serum or TBS, as well as omission of the secondary antiserum or ABCElite. These preliminary observations guaranteed the specificity of antisera and methods.

\section{Results}

\section{Macroscopic and histopathological findings}

Major macroscopic and histopathological findings of each case in mice and rats are summarized in Table 2. Macroscopically, pituitary glands with pars intermediate adenoma were almost slightly or moderately enlarged or colored dark red, and were well defined and separated from the brain. In these features, they resembled a common pars distalis tumor but none of them were enlarged markedly with compression atrophy of

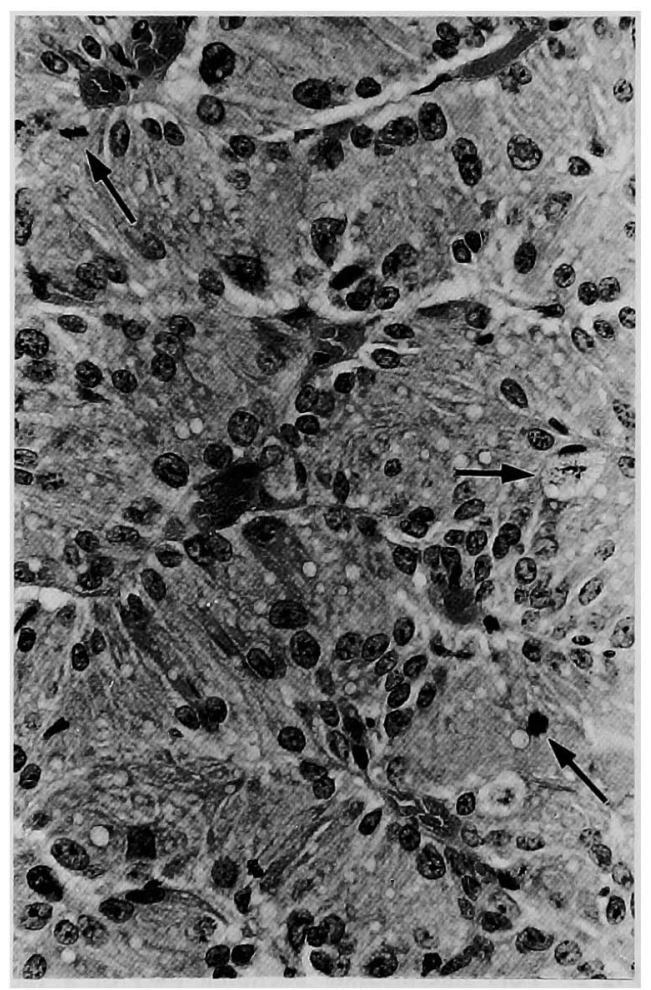

Fig. 3. High-power view of Fig. 1. Showing elongated tumor cells with prominent nucleoli arranged in parallel groups and some mitotic figures (arrows). Case 2., H.E., $\times 450$ the adjacent brain parenchyma.

In general architecture, adenomas of the pars intermedia were found as nodules in various sizes with compression of adjacent pituitary parenchyma (Fig. 1). Large pars intermediate adenomas grew expansively, and replaced the normal pars intermedia and nervosa completely (Cases 4 and 5, Fig. 2), but no case invaded to the other organs or tissues or showed distant metastasis. Some adenomas occupied focal areas indicated borders to adjacent normal pars intermedia by different cell morphology, and invaded the pars distalis or nervosa (Cases 1 and 3). However, the tumor cells manifested a morphological continuum to normal cells of the pars intermedia, they had relatively abundant cytoplasms and were eosinophilic. They often showed increasing size with a large nucleus containing prominent nucleoli (Cases 2, 3, and 6), sometimes were elongated and arranged in parallel groups (Case 2, Fig. 3). In Case 3, the tumor contained atypical or bizarre giant cells (Fig. 4 ), but in other cases, atypicality

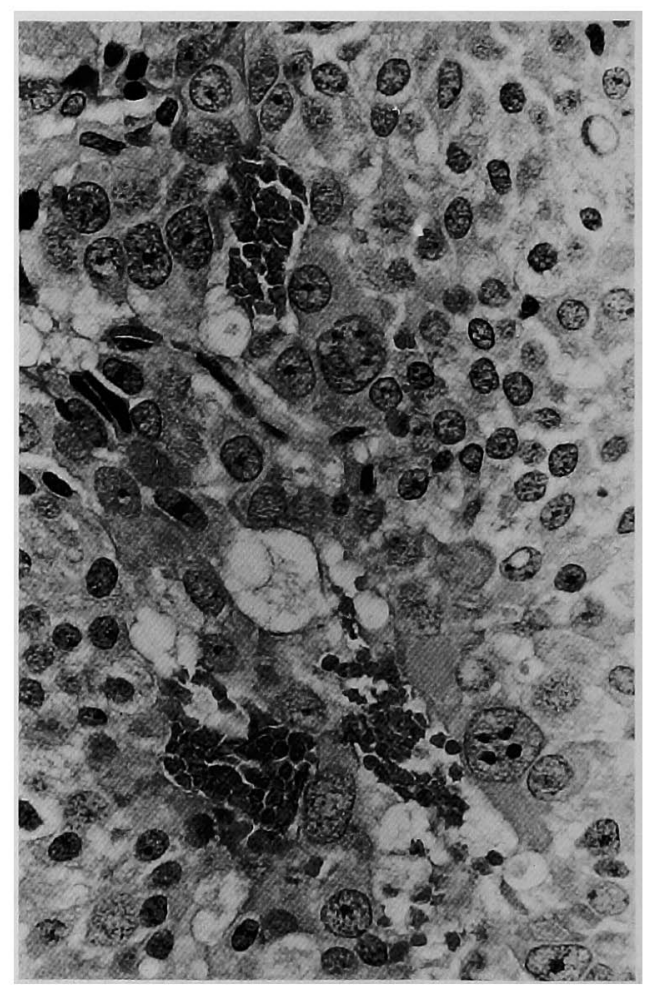

Fig. 4. Adenoma of the pars intermedia containing atypical giant cells and large eosinophilic cells with prominent nucleoli. Case 3., H.E. $\times 450$ 


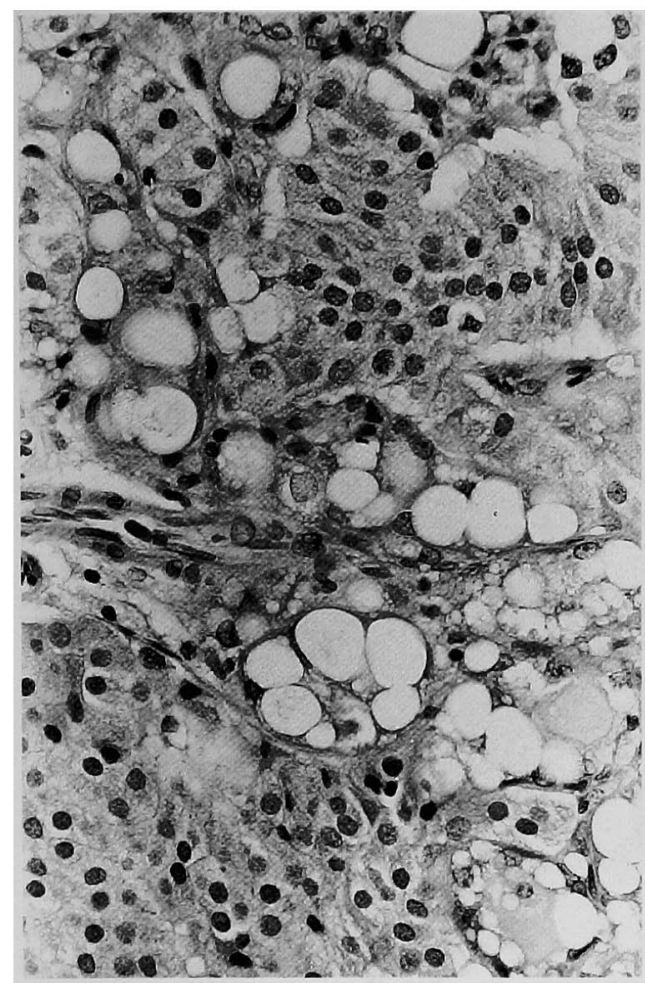

Fig. 5. Vacuolated cell nests in the pars intermediate adenoma in a rat. Note the morphological continuum with more typical tumor cells. Case 4., H.E. stain, $\times 300$

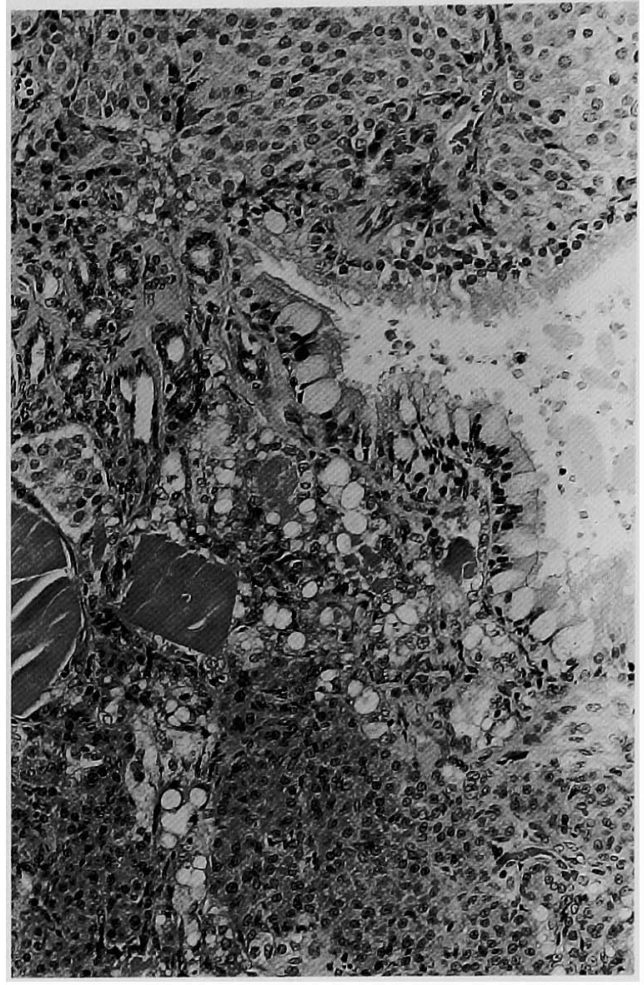

Fig. 6. Showing colloidal follicular structures and a cyst lined with ciliated columnar epithelium in a large adenoma of the pars intermedia. Case 4., H.E. stain, $\times 150$

(Table 2)

\section{Immunocytochemical findings}

Before describing our immunocytochemical studies of pars intermediate adenomas, it is necessary to explain the immunocytochemical reactions of normal cells in the pars intermedia, distalis, and nervosa in both mice and rats. While the normal pars intermedia stained diffusely and strongly with antibodies against $\mathrm{ACTH}{ }^{1-39}, \beta$-END, $\alpha$-MSH, $\beta-\mathrm{MSH}$, and $\gamma-\mathrm{MSH}$, a few specific cells in the pars distalis reacted with these antibodies except for $\alpha$-MSH. With anti- $\alpha$-MSH antiserum, no immunostaining reaction was found in any cell of the pars distalis. In the pars nervosa, any stainable reaction was not found. No difference of immuno-reactivity was found between the mouse and rat pituitary glands.

Adenomas derived from the pars intermedia in mice and rats, had a uniform pattern of immunoreactivity with antiserum against $\mathrm{ACTH}^{1-39}$, pathological feature including neoplastic and nonneoplastic lesions in the other organs and tissues 


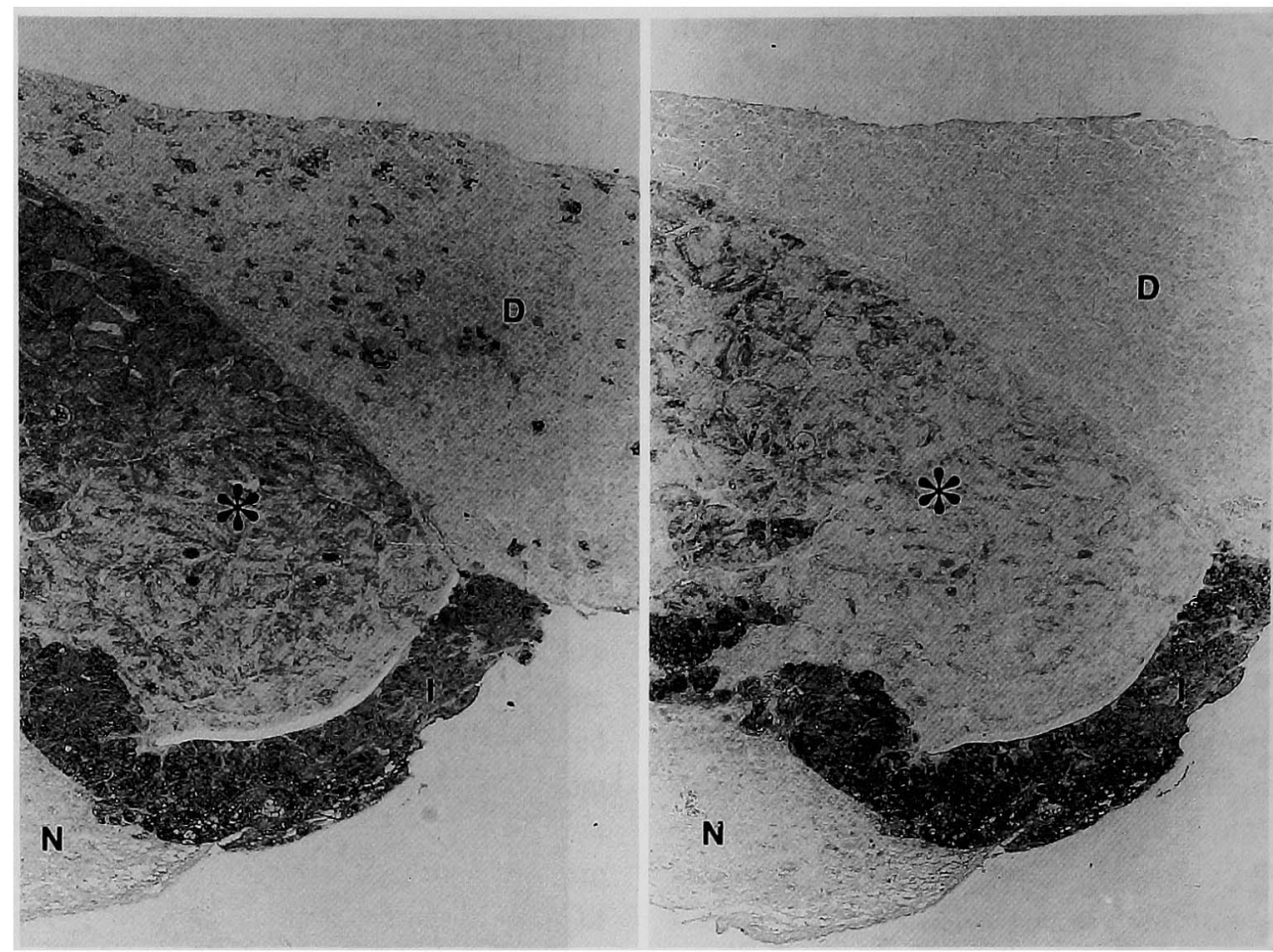

Fig. 7a.

Fig. $7 b$.

Fig. 7. Immunocytochemistry of adenomas arising from the pars intermedia (*) in a mouse. 7a: immunostaining for $\mathrm{ACTH}^{1-39}$. 7b : immunostaining for $\alpha$-MSH of the same portion in $7 \mathrm{a}$. Note no reaction in any cells of the pars distalis. $\mathrm{D}:$ the pars distalis, $\mathrm{N}$ : the pars nervosa, $\mathrm{I}:$ the normal pars intermedia. Case $2 ., \times 75$

$\beta$-END, $\alpha-\mathrm{MSH}, \beta-\mathrm{MSH}$, or $\gamma-\mathrm{MSH}$. In all cases, tumor cells were stained with all antisera against POMC-derived peptides. When compared with staining intensities of normal pars intermediate cells, the tumor cells were weakly stained. In the immunostained sections, pars intermediate adenomas often gave speckled feature since tumor cells had variations in staining intensity in different cells and portions. Moreover, in the same section, immunostaining features with individual POMC-related peptides were subtly different (Figs. 7 and 8). As same as positive immunoreactivity of non-vacuolated tumor cells, scanty cytoplasm of vacuolated cells in Cases 4 and 5 was immunopositive with all obtained antibodies (Fig. 9). Contrary to positive reactions of these tumor cells, follicular structures with colloid and ciliated columnar cells forming a large cyst were not immunostained at all.

\section{Discussion}

This study established the histopathological and immunocytochemical features of pituitary adenomas arising from the pars intermedia in aging mice and rats. The morphology of the rat pars intermediate tumors has been described ${ }^{2,9,10}$ but in the mouse, there appears to be only one report and one textbook mentioning the pars intermediate tumor ${ }^{14,18}$. In the main, our morphological findings of pars intermediate adenomas agreed well with those reported for both rats and mice. In the one report on mice, nine intermediate tumors were found in 900 female virgin Han : NMRI mice older than 19 months $^{14}$. In another publication, the pathological details were not described $^{18}$. Four cases of pars intermediate tumors, three in male and one in female, in 192 male and 192 female 30-month-old Wistar rats were described ${ }^{9}$. In this report, an interesting 


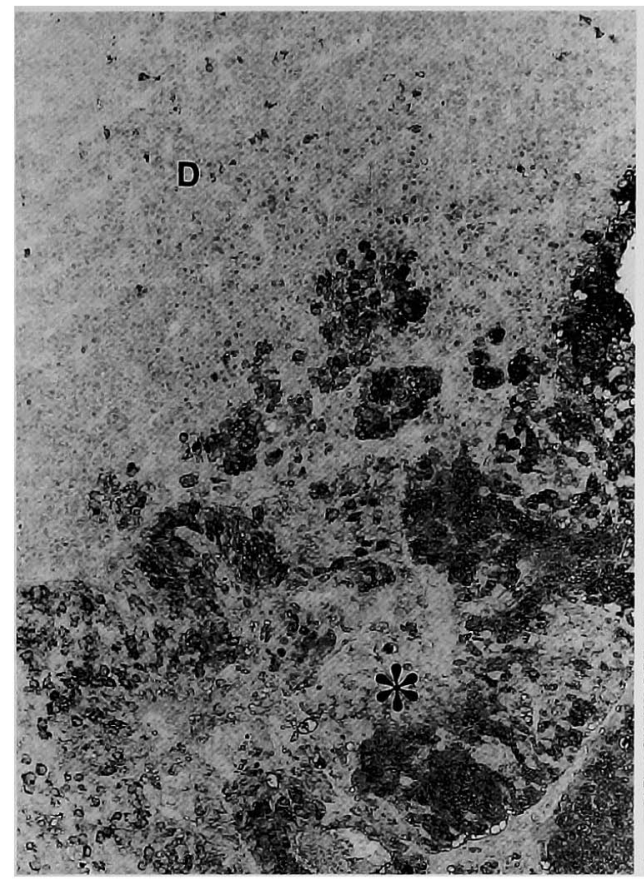

Fig. 8a.

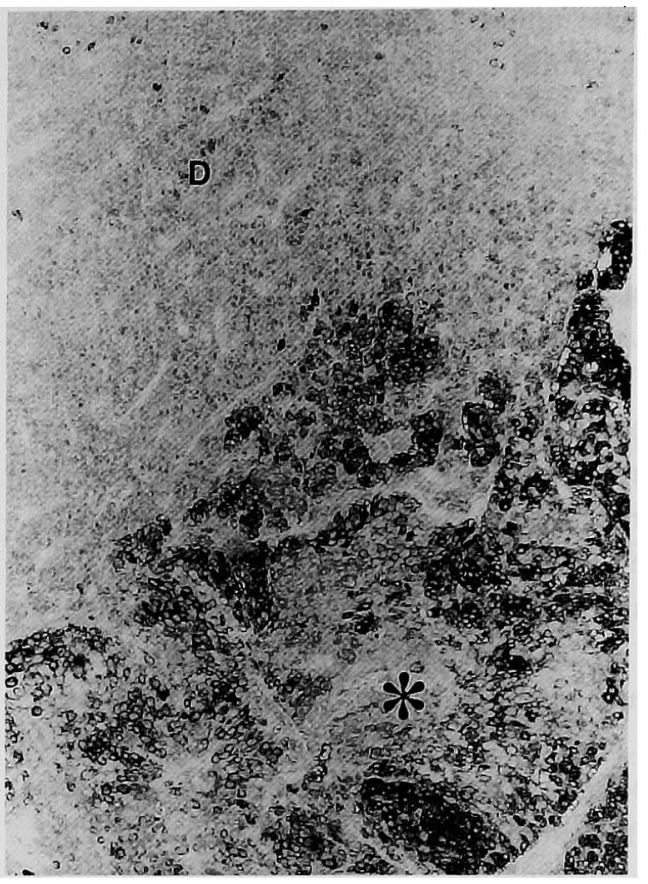

Fig. 8b.

Fig. 8. Immunocytochemistry of the pars intermediate adenoma $(*)$ in a rat. $8 \mathrm{a}$ : immunostaining for $\beta$-MSH. $\quad 8 \mathrm{~b}:$ immunostaining for $\beta$-END of the same portion in $8 \mathrm{a} . \quad \mathrm{D}:$ the pars distalis. Case 5., $\times 75$

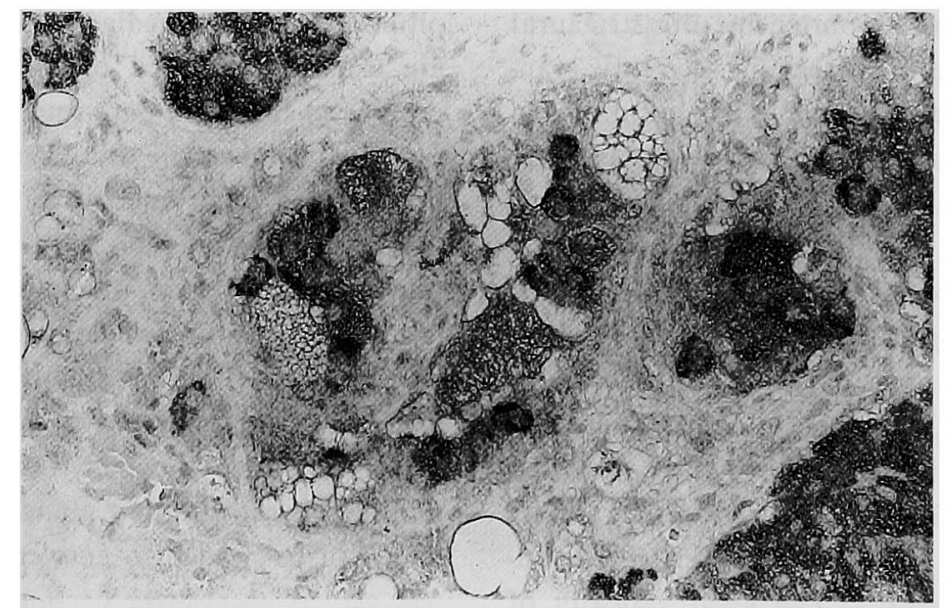

Fig. 9. Showing immunopositive reaction of vacuolated cell nests with anti- $\gamma$-MSH antiserum in Case $4 ., \times 300$

tumor containing islet of hyperplastic intermediate cells and tubular structures filled with colloid and vacuolated cell nests was identified as not a tumor of the pars intermedia but a miscellaneous tumor. This tumor was closely similar to our Cases 4 and 5. In our cases, the vacuolated cell nests contain- ing POMC-derived peptide and were morphologically continuous with the more typical tumor cells of pars intermediate adenomas. These facts suggested that the vacuolated cell nests originated from neoplastic intermediate cells, and that this tumor should also be classified as a pars 
intermediate tumor. On the other hand, the follicular structures and ciliated columnar cells of a large cyst in Case 4 did not immunostain with any POMC-derived peptides. The origin of these structures is not yet clear, but they are often present in equine ${ }^{19}$ and canine ${ }^{20}$ pars intermediate adenomas as associated or main components. In aged rat pituitary glands, these structures are occasionally seen in the nonneoplastic pars intermedia or nervosa, and they have been suggested as persistent remnants of Rathke's pouch ${ }^{21}$. Therefore, we considered these structures to be discontinuous with the tumor cells.

While the intermediate lobe of the pituitary gland is a major part of the POMC system in both mice $^{16}$ and rats ${ }^{15}$, in tumor cells of the pars intermediate adenoma, no survey in mice and only a few studies in rats have examined these immunocytochemically connections. An earlier study in rats reported no detectable hormone in the pars intermediate tumor cells, when examined immunocytochemically for TSH, PRL, GH, and ACTH ${ }^{9}$. The later studies succeeded to demonstrate that the adenoma cells of the pars intermedia contained immunoreactive ACTH ${ }^{10,11}$ and $\alpha$ $\mathrm{MSH}^{10}$, and this was supported by ultrastructural findings in tumor cells containing secretory granules measuring $100-300 \mathrm{~nm}^{11}$. In addition to these investigations, our examinations clearly demonstrated that tumor cells of the pars intermediate adenoma, not only in rats but also in mice, contain major POMC-related peptides: ACTH, $\alpha$-MSH, $\beta$-MSH, $\gamma$-MSH, and $\beta$-END. These facts show that adenomas of the pars intermedia in both mice and rats are endocrinologically active in a way similar to the more commonly-observed tumors in the pars distalis. Tumors of the rat pars distalis have been thoroughly investigated immunohistopathologically. The great majority of spontaneous pars distalis tumors of rat pituitary glands contain immunoreactive prolactin ${ }^{9,11,22}$, and it has been suggested that the presence of prolactin bears some relation to hyperplastic or neoplastic changes in mammary glands ${ }^{23}$. In this study, both mice and rats having pars intermediate adenoma showed no convincing evidence of endocrinological effects of their containing POMCrelated peptides to other organs or tissues includ- ing adrenal glands. In other animals, however, there are interesting reports of pars intermediate tumors affecting other organs and causing functional and behavioral changes. Pituitary tumors in horses almost always arise from the pars intermedia ${ }^{19.24}$, unlike those in human beings, mice, and rats. These equine tumors contain immunoreactive POMC, ACTH, $\alpha-\mathrm{MSH}$, and $\beta$ END in their cytoplasms ${ }^{19}$, and moreover horses bearing these tumors manifest hyperglycemia ${ }^{24}$, Cushing's disease ${ }^{25,26}$ docility, and diminished responsiveness to painful stimuli and/or diffuse adrenal cortical hyperplasia ${ }^{19}$. In the dog also, the pars intermediate tumors contain immunoreactive $\mathrm{ACTH}$ and $\mathbf{M S H}^{27}$, and excessive secretion of ACTH led to bilateral adrenocortical hyperplasia ${ }^{20}$. Although there is no available data on the serum concentrations of POMCrelated peptides in mice and rats bearing the pars intermediate tumors, the tumor cells produce and contain these peptides. However, the tumor cells may not secrete these peptides actively, since no histopathological abnormalities were detected in the adrenal glands in any of our cases.

In contrast with animals, in human beings, the pituitary pars intermedia are poorly developed and are usually composed of small cysts, the tumor developed from the pars intermedia has not been reported up to now. Pituitary tumors of the pars distalis may occur at relatively high incidences in female mice ${ }^{28}$ and rats ${ }^{6}$ than in males. Pituitary tumors derived from the pars intermedia occur more frequently in female horses than in males ${ }^{19}$, but there is no information on whether such sexual differences in incidence exist in mice and rats. With respect to the pars intermediate tumor of mouse and rat pituitary glands, more background data will be needed to answer the question.

\section{References}

1. Ward, JM, Goodman, DG, Squire, RA, Chu, KC, and Linhart,MS: Neoplastic and nonneoplastic lesions in aging $(\mathrm{C} 57 \mathrm{BL} \times \mathrm{C} 3 \mathrm{H} / \mathrm{HeN}) \mathrm{F}_{1}\left({\left.\mathrm{~B} 6 \mathrm{C} 3 \mathrm{~F}_{1}\right)}\right)$ mice. J Natl Cancer Inst 63 : 849-854, 1979.

2. Anver, MR, Cohen, BJ, Lattuada, CP, and Foster, SJ: Age-associated lesions in barrier-reared male Sprague Dawley rats : a comparison between Hap : (SD) and $\mathrm{Crl}$ : $\mathrm{COBS}^{[R]} \mathrm{CD}^{[R]}$ (SD) stocks. Exp 
Aging Res 8: 3-24, 1982.

3. Maekawa, A, Kurokawa, Y, Takahashi, M, Kokubo, T, Ogiu, T, Onodera, H, Tanigawa, H, Ohno, Y, Furukawa, F, and Hayashi, Y : Spontaneous tumors in F-344/DuCrj rats. Gann 74: 365-372, 1983.

4. Solleveld, HA, Haseman, JK, and McConnell, EE : Natural history of body weight gain, survival, and neoplasia in the F344 rat. J Natl Cancer Inst 72 : 929-940, 1984.

5. Maekawa, A, Onodera, H, Tanigawa, H, Furuta, K, Matsuoka, C, Kanno, J, Ogiu, T, and Hayashi, Y : Spontaeous neoplastic and non-neoplastic lesions in aging Donryu rats. Gann 77: 882-890, 1986.

6. Haseman, JK, Huff, J, and Boorman, GA : Use of historical control data in carcinogenicity studies in rodents. Toxicol Pathol 12: 126-135, 1984.

7. Tamano, S, Hagiwara, A, Shibata, M, Kurata, Y, Fukushima, $\mathbf{S}$, and Ito, $\mathbf{N}$ : Spontaneous tumors in aging $(\mathrm{C} 57 \mathrm{BL} / 6 \mathrm{~N} \times \mathrm{C} 3 \mathrm{H} / \mathrm{HeN}) \mathrm{F}_{1}\left(\mathrm{~B} 6 \mathrm{C} 3 \mathrm{~F}_{1}\right)$ mice. Toxicol Pathol 16: 321-326, 1988.

8. Bomhard, E and Mohr, U : Spontaneous tumors in NMRI mice from carcinogenicity studies. Exp Pathol 36: 129-145, 1989.

9. Berkvens, JM, Van Nesselrooy, JHJ, and Kroes, R : Spontaneous tumours in the pituitary gland of old Wistar rats: A morphological and immunocytochemical study. J Pathol 130: 179-191, 1980.

10. Lee, AK, DeLellis, RA, Blount, $M$, Nunnemacher, $\mathrm{G}$, and Wolfe, $\mathrm{HJ}$ : Pituitary proliferative lesions in aging male Long-Evans rats: A model of mixed multiple endocrine neoplasia syndrome. Lab Invest 47: 595-602, 1982.

11. McComb, DJ, Kovacs, K, Beri, J, and Zak, F : Pituitary adenomas in old Sprague-Dawley rats : A histologic, ultrastructural, and immunocytochemical study. J Natl Cancer Inst 73 : 1143-1166, 1984.

12. Attia, MA : Neoplastic and nonneoplastic lesions in aging female rats with special reference to the functional morphology of the hyperplastic and neoplastic changes in the pituitary gland. Arch Toxicol 57: 77-83, 1985.

13. Sandusky, GE, Van Pelt, CS, Todd, GC, and Wightman, K: An immunohistochemical study of pituitary adenoma and focal hyperplasia in old Sprague-Dawley and Fisher 344 rats. Toxicol Pathol 16: 376-380, 1988.

14. Rehm, S, Rapp, KG, and Deerberg, F : Influence of food restriction and body fat on life span and tumour incidence in female outbred Han: NMRI mice and two subline. Z Versuchtierk $27: 249-283$, 1985.

15. Gianoulakia, C, Seidah, NG, Routhier, R, and Chrêtien, $\mathbf{M}$ : Biosynthesis and characterization of adrenocorticotropic hormone, $\alpha$-melanocyte-stimulating hormone, and an $\mathrm{NH}_{2}$-terminal fragment of the adrenocorticotropic hormone/ $\beta$-lipotropin precursor from rat pars intermedia. J Biol Chem 254 :
11903-11906, 1979.

16. Jenks, BG, Van Daal, JHHN, Scharenberg, JGM, Martens, GJM, and Van Overbeeke, AP: Biosynthesis of proopiomelanocortin-drived peptides in the mouse neurointermediate lobe. J Endocrinol 98 : 19-34, 1983

17. Marx, JL : Synthesizing the opioid peptides. Science 220 : 395-397, 1983.

18. Frith, $\mathrm{CH}$ and Ward, JM : Endocrine system. In : Color atlas of neoplastic and non-neoplastic lesions in aging mice. Elsevier, Amsterdam, pp. 33-48, 1988.

19. Heinrichs, $M$, Baumgärtner, $W$, and Capen, $C C$ : Immunocytochemical demonstration of proopiomelanocortin-derived peptides in pituitary adenomas of the pars intermedia in horses. Vet Pathol 27 : 419-425, 1990.

20. Capen, CC, Martin, SL, and Koestner, A : Neoplasms in the adenohypophysis of dogs. Path Vet 4: $301-325,1967$.

21. MacKenzie, WF and Boorman, GA: Pituitary gland. In: Pathology of the Fisher rat. GA, Boorman, SL, Eustis, MR, Elwell, CA, Montgomery, and WF, MacKenzie Eds, Academic Press, San Diego, pp. 485-500, 1990.

22. Kovacs, K, Horvath, E, Ilse, RG, Ezrin, C, and ILse, $\mathrm{D}$ : Spontaneous pituitary adenomas in aging rats : A light microscopic, immunocytological, and fine structure study. Beitr Pathol 161: 1-16, 1977.

23. Attia, MA : Neoplastic and nonneoplastic lesions in aging female rats with special reference to the functional morphology of the hyperplastic and neoplastic changes in the pituitary gland. Arch Toxicol 57: 77-83, 1985.

24. Loeb, WF, Capen, CC, and Johnson, LE : Adenoma of the pars intermedia associated with hyperglycemia and glycosuria in two horses. Cornell Vet 56 : 623 639, 1966.

25. Moore, JN, Steiss, J, Nicholson, WE, and Orth, DN : A case of pituitary adrenocorticotropin-dependent Cushing's diseases in the horse. Endocrinology 104: 576-582, 1979.

26. Wilson, MG, Nicholson, WE, Holscher, MA, Sherrell, BJ, Mount, CD, and Orth, DN : Proopiolipomelanocortin peptides in normal pituitary, pituitary tumor, and plasma of normal and Cushing's horses. Endocrinology 110: 941-954, 1982.

27. El Etreby, MF, Müller-Peddinghaus, R, Bhargava, $A S$, and Trautwein, G : Functional morphology of spontaneous hyperplastic and neoplastic lesions in the canine pituitary gland. Vet Pathol 17:109$122,1980$.

28. Schechter, JE, Felicio, LS, Nelson, JF, and Finch, CE: Pituitary tumorigenesis in aging female C57BL/6J mice: A light and electron microscopic study. Anat $\operatorname{Rec} 199$ : 423-432, 1981. 